\title{
Impactos socioambientais e econômicos do turismo e as suas repercussões no desenvolvimento local: o caso do Município de Itacaré - Bahia
}

Socio-environmental and economic impacts of the tourism and its repercussions in the local development: the case of the municipality of Itacaré - Bahia

Impacts économiques et Socio-environnementaux du tourisme et ses repercussions dans le développement local: le cas de la municipalité d'Itacaré - Bahia Impactos socioambientales y económicos del turismo y sus repercusiones en el desarrollo local: el caso del municipio de Itacaré - Bahia

\section{Elton Silva Oliveira*}

Recebido em 9/6/2006; revisado e aprovado em 20/1/2007; aceito em 10/8/2007

\begin{abstract}
Resumo: Na Bahia, nordeste brasileiro, o turismo tem se revelado uma alternativa atraente para o desenvolvimento econômico da região Costa do Cacau e, destacadamente para o município de Itacaré, que desponta na preferência dos turistas nacionais e internacionais que freqüentam o sul do Estado na alta estação. Neste sentido, o objetivo do presente trabalho é efetuar um estudo dos impactos sócio-ambientais e econômicos do turismo e suas repercussões no desenvolvimento local.

Palavras-chave: desenvolvimento local; impactos sócio-ambientais; turismo.

Abstract: In the Bahia, brazilian northeast, the tourism has been disclosed as an attractive alternative for the economic development of the region Coast of the Cacao and especially for the municipality of Itacaré, that blunts in the preference of the national and international tourists, who frequent the south of the State in the high station. In this direction, the objective of the present work is to make a study of the socio-environmental and economic impacts of the tourism and its repercussions in the local development.

Key words: local development; socio-environmental impacts; tourism.

Résumé: À Bahia, situé au nord-est du Brésil, le tourisme se révèle être une alternative atractive pour le développement économique de la région de la Côte du Cacao et, surtout pour la municipalité d'Itacaré, destination préférée des touristes nationaux et internationaux qui fréquentent le sud de l’État en période de haute saison. En ce sens, l’objectif de ce travail est de faire une étude des impacts économiques et socio-environnementaux et ses repercussions dans le développement local.

Mots-clés: développement local; impacts socio-environnementaux; tourisme.

Resumen: En Bahia, nordeste brasileño, el turismo se ha revelado como una alternativa atrayente para el desarrollo económico de la región Costa del Cacao y, destacadamente para el municipio de Itacaré, que despunta em la preferencia de turistas nacionales e internacionales que frecuentan el sur del Estado en la alta estación. En este sentido, el objetivo del presente trabajo es efectuar um estudio de los impactos socioambientales y económicos del turismo y sus repercusiones en el desarrollo local.

Palabras-clave: desarrollo local; impactos socioambientales; turismo.
\end{abstract}

\section{Considerações iniciais}

O maior volume de estudos científicos sobre turismo provém das ciências econômicas, que analisam o crescimento e a movimentação de capitais a partir da chamada "indústria" do turismo, ou seja, dos negócios turísticos. Mas estes são apenas uma parte dessa atividade, que vem se configurando como um fato social total (BARRETO, 2003).

O turismo, dentro dos moldes atuais, iniciou-se, efetivamente, na segunda metade do século XIX. No entanto, a atividade estende suas raízes pela história da humanidade. Destarte, conquanto algumas formas de turismo existem desde as mais antigas civilizações, somente a partir do século $\mathrm{XX}$, e mais precisamente a partir da década de 50, que ele evoluiu, projetando-se como um dos mais importantes setores econômicos do Mundo (LAGE; MILONE, 2000; RUSCHMAN, 1997).

No atual processo de globalização econômica, o turismo - que entre 1950 e 1990 cresceu em torno dos 7\% ao ano (OMT, 2003) - tornou-se uma fonte de renda e, não raro,

\footnotetext{
* Professor da FACSUL (Faculdade do Sul) e Mestrando em Cultura e Turismo UESC (Universidade Estadual de Santa Cruz) / UFBA (Universidade Federal da Bahia); Membro do Núcleo Temático de Turismo para o Desenvolvimento Regional - NTT. Bacharel em Ciências Econômicas pela UESC. Bolsista da FAPESB (Fundação de Amparo à Pesquisa do Estado da Bahia). Travessa Castro Alves, 34 - Centro - Itabuna - Bahia. CEP: 45.600-000. Correio Eletrônico: srelton@hotmail.com.
} 
setor mais forte no financiamento da economia nacional, em muitos países. Se o turismo fosse uma nação, ou um estado independente, seria agora, a terceira potência econômica do mundo, situando-se somente atrás dos Estados Unidos e do Japão. Uma explicação para este crescimento é que o turismo é uma atividade econômica de múltiplos componentes, na qual muitas partes estão intrinsecamente associadas a outros setores econômicos: aviação, transporte rodoviário, marítimo e fluvial, lojas de souvenirs, stands de concessionárias, restaurantes e bares, casas noturnas, parques temáticos, serviço de hotéis, agências de viagens e operadoras turísticas, entre outros cinqüenta itens da economia, tornando-o a maior atividade geradora de empregos, e estimulando os investimentos internacionais (MOESCH, 2002).

É importante ressaltar que o turismo está entre as quatro principais atividades econômicas do mundo e, hoje, apresenta os mais elevados índices de crescimento em nível global, respondendo por aproximadamente $10 \%$ do PIB mundial, representando investimentos de capital superiores a US\$ 766 bilhões em novas instalações e equipamentos. $\mathrm{A} \mathrm{OMT}^{1}$, por sua vez, prevê um crescimento no setor de $4 \%$ a $5 \%$ por ano, podendo atingir a meta de 6,7\% no ano de 2020, enquanto se estima para a economia mundial, em seu todo, um crescimento inferior a 3\% (BARTELÓ, 2000).

No Brasil e em diversos outros países, o turismo é um dos mais relevantes setores da atividade econômica. Sua contribuição para a criação de riquezas e melhoria do bem-estar dos cidadãos pode ser sentida de múltiplas maneiras: pela geração de emprego; pela distribuição e circulação de renda; pela transferência de recursos de regiões mais ricas para regiões menos favorecidas; pelos investimentos e inovações que promove; pelo desenvolvimento de infra-estruturas coletivas que estimula; pela preservação do ambiente e recuperação do patrimônio histórico e cultural; pelas oportunidades de desenvolvimento regional que representa; e, pelas necessidades dos indivíduos viajantes que satisfaz. Esses efeitos interagem em diversos domínios da sociedade e, de maneira geral, envolvem os ambientes: cultural, ecológico, econômico, político e social.
No Brasil, o setor turístico vem atraindo de modo progressivo a atenção dos governantes e demais autoridades responsáveis pelo planejamento de políticas públicas, por se tratar de um setor com grande vocação para a geração de emprego, renda e desenvolvimento socioeconômico, constituindo um efeito importante em termos de política econômica.

No que tange ao Nordeste brasileiro, este se apresenta com amplos potenciais de desenvolvimento no âmbito do turismo. Seu litoral é um grande receptor de investimentos turísticos mundiais. Os estados que compõem a região apresentam um grande potencial ou vocação turística, haja vista seus inúmeros atrativos.

Concernente ao Estado da Bahia, atualmente, observa-se um grande número de estudos e projetos realizados pelo Governo do Estado destinados ao setor turístico, tendo em vista o melhor aproveitamento de suas potencialidades culturais, históricas, naturais, redefinindo o espaço territorial baiano através do desenvolvimento turístico.

Face aos investimentos maciços em infra-estrutura, construção e modernização de equipamentos efetuados pelo Governo da Bahia, adicionando a uma política intensiva de projeção do Estado no Brasil e no exterior, o turismo alcançou, no ano de 2000, uma receita global de US\$ 856,7 milhões correspondente a $6,2 \%$ do PIB baiano (BARTELÓ, 2000). Merecem destaque, ainda, os investimentos realizados pela iniciativa privada, sobretudo no âmbito de implantação e crescimento da rede hoteleira, destacando-se os meios de hospedagem do tipo Resort (BONFIM, 2001).

No cenário atual, os investimentos do Governo do Estado da Bahia em conjunto com os investimentos privados representam um grande efeito indutor na economia, ao garantir a criação de empregos, empresas e, principalmente, mais renda. A Bahia, atualmente, vem se destacando como maior pólo de investimentos turísticos do Brasil (BARTELÓ, 2000).

O Estado da Bahia, esta recebendo investimentos privados, oriundos de grupos espanhóis e portugueses da ordem de 1 bilhão de reais, destinados a construção de 5 Resorts, localizados na Costa dos Coqueiros, Baía de Todos os Santos, Costa do Cacau e Costa do Descobrimento, que estarão em 
pleno funcionamento até setembro de 2007 (BAHIATURSA, 2005).

Situado na Costa do Cacau, o Município de Itacaré, atualmente, encontra-se no seu terceiro ciclo de desenvolvimento: após o descobrimento, cultivou-se a cana-deaçucar em áreas da floresta atlântica desmatadas pela extração do pau-brasil; em seguida, a monocultura cacaueira e, hoje o turismo (DOLIS, 2004).

A Costa do Cacau, localizada no litoral Sul da Bahia, compreende os Municípios de Canavieiras, Ilhéus, Itacaré, Santa Luzia, Una, Uruçuca, contando, a partir do ano de 2004, com o Município de Itabuna. Nela, o turismo tem se desenvolvido com investimentos de empresários nacionais e estrangeiros. Nos últimos anos, a oferta de serviços e infra-estrutura cresceu na proporção da demanda da alta estação. Os turistas são atraídos para verdadeiros santuários ecológicos tropicais: dezenas de quilômetros de praias, com densos coqueirais, que se unem à variedade da vegetação, desde a Mata Atlântica nativa a extensas áreas de manguezais e fazendas de cacau (Ibidem). Tais atrativos promovem, além do turismo tradicional, e o de caráter ecológico.

O ecoturismo é uma viagem responsável a áreas naturais, visando preservar o meio ambiente e promover o bem estar da comunidade local. Porém sob a égide do ecoturismo vem se praticando uma má interpretação do conceito. Muitas localidades são divulgadas devido ao potencial ecoturístico, embora a atividade praticada não seja caracterizada como tal (LINDIBERG; HAWKINS, 1999).

Dentro da sua essência, a atividade ecoturística deve se desenvolver respeitando critérios socioambientais que irão dar sustentabilidade a atividade, porém o que se observa na prática, em algumas localidades de potencial ecoturístico é uma distorção deste conceito ou a apropriação de roteiros ecoturísticos por outras modalidades de turismo, ou seja, a exploração dos ambientes naturais pelo turismo sem nenhum respeito a estes critérios. Assim, há uma distorção da realidade local, que nem sempre usufrui os benefícios do turismo e ainda arca com uma série de impactos por ele ocasionado.

O Município de Itacaré apresenta um quadro exemplar desta controvérsia. É um destino que se destaca por seu potencial ecoturístico, e que, após a pavimentação em 1998, da Estrada Parque a BA-001 que liga o Município de Ilhéus a Itacaré começou a receber um intenso fluxo de turistas e de migrantes que buscavam oportunidades nesta nova opção econômica. $\mathrm{O}$ despreparo do Município para receber este contingente de pessoas se revela em sua infra-estrutura precária e na falta de planejamento socioambientais e culturais enfrentados pelo Município hoje, embora sejam inegáveis alguns benefícios promovidos por este fenômeno.

Nesse contexto, encontramos o Município de Itacaré, possuidor de um grande potencial ecoturístico, com problemas sociais que se agravam em função do grande crescimento demográfico acelerado em função da atividade turística. Inicialmente, o turismo se apresentou como uma alternativa atraente para o desenvolvimento do Município, trazendo benefícios à comunidade local e principalmente à economia que se encontrava estagnada. Após o rápido crescimento da atividade turística, devido à falta de planejamento, infra-estrutura e mão-de-obra qualificada, o turismo como uma indústria de várias chaminés, tem revelado neste núcleo receptor as suas outras faces: aumento da violência, degradação ambiental, especulação imobiliária, importação e em conseqüência disto vazamento da renda, inflação, ocupação desordenada dos espaços urbanos, aumento dos índices de prostituição e do tráfico de drogas e entorpecentes.

O objetivo do presente trabalho é efetuar um estudo das repercussões do turismo no desenvolvimento dessa localidade. Tratase de uma pesquisa exploratória, quali-quantitativa, documental, com base em dados secundários provenientes de organismos públicos e privados, tais como: BAHIATURSA ${ }^{2}$, $\mathrm{BID}^{3}, \mathrm{BNB}^{4}, \mathrm{IBGE}^{5}, \mathrm{IESB}^{6}, \mathrm{ITI}^{7}, \mathrm{TOI}^{8}$, além de consulta a anuários estatísticos, artigos, jornais, monografias, livros, periódicos e teses. Os aspectos qualitativos foram priorizados em detrimentos dos quantitativos, devido ao caráter social do tema.

A estruturação deste trabalho está dividida de forma que o leitor, no primeiro momento, conheça o Município, sua população, localização geográfica, o clima, a sua história, entre outras. No segundo, eviden- 
cia-se os impactos socioambientais gerados através da pavimentação de $65 \mathrm{Km}$ da Estrada Parque (BA-001) que liga o Município de Ilhéus a Itacaré, que se configurou como um vetor de desenvolvimento regional e local, atraindo empresários de outras regiões e de outros países (SOUZA, 2005). Logo após, apresentaremos os impactos econômicos gerados pelo significativo aumento do fluxo de turistas para Itacaré, que no ano de 2005, passou a receber cerca de 120 mil turistas, um número seis vezes maior que a sua população (ITI, 2005). Por Fim, faremos uma análise crítica quanto ao atual modelo de desenvolvimento em curso neste núcleo receptor, de forma lúcida, pois temos plena consciência de que o turismo não será a panacéia para todos os problemas verificados no Município foco deste estudo.

\section{O locus}

O Município de Itacaré - BA, está localizado na região Costa do Cacau, no Esta- do da Bahia, ao Sul de Salvador, a uma distância de 532 Km via BR-101 e BR-324 e, ao Norte de Ilhéus, a uma distância de $65 \mathrm{Km}$ via BA-001. Ocupa uma área de 730,27 Km², a $14^{\circ} 18^{\prime}$ de latitude Sul e $39^{\circ} 02^{\prime}$ de longitude Oeste do Meridiano de Greenwich, e que segundo o IBGE (2000), possui uma população de 18.120 habitantes sendo que 53,06\% desta, são de indivíduos do sexo masculino, e que ainda $56,12 \%$ reside na zona rural.

A cidade de Ilhéus é o portão de entrada aéreo, marítimo e rodoviário para o Município de Itacaré. O principal acesso rodoviário para a Cidade de Ilhéus é a BR-101. O Município de Ilhéus, conta, ainda, com um Aeroporto que é servido por vôos diários, bem assim como com um Porto que recebe estrangeiros de navios de toda a parte do mundo.

O clima do Município de Itacaré é tropical. As temperaturas variam entre $25^{\circ} \mathrm{C}$ e $30^{\circ} \mathrm{C}$, podendo chegar aos $40^{\circ} \mathrm{C}$ durante a alta temporada (dezembro, janeiro e fevereiro). Chuvas freqüentes ocorrem durante o inverno (de maio a agosto).

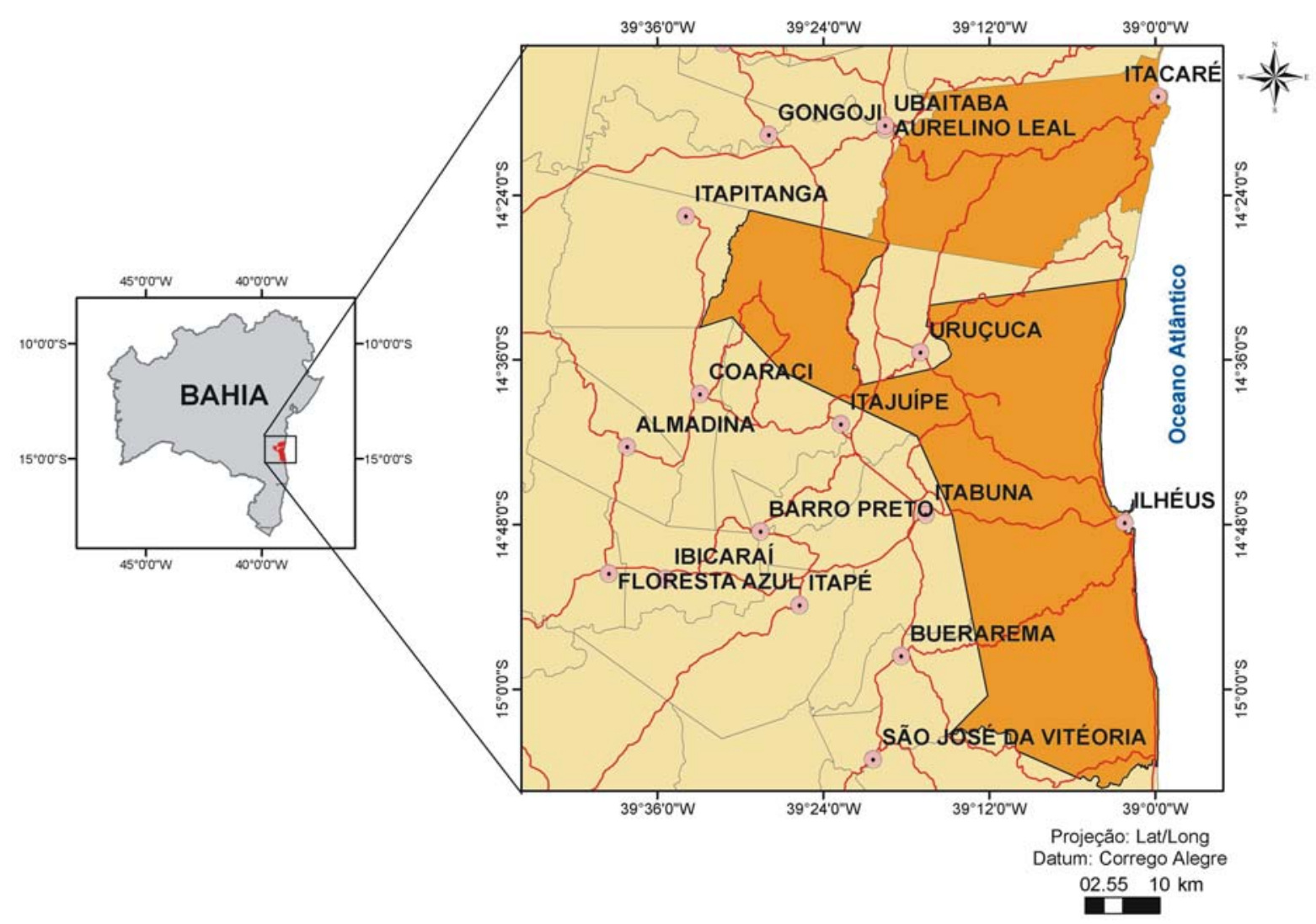

Figura 1 - Mapa da localização do Município de Itacaré - Bahia.

Fonte: MOREAU (2006). 
A história de Itacaré data das Capitanias Hereditárias. Em 1530 chegaram os primeiros colonizadores, expulsando os índios tupiniquins e introduzindo o cultivo da canade-açúcar e a religião católica. Em 1718, com a construção da Igreja de São Miguel, o povoado passou a se chamar São Miguel da Barra do Rio de Contas. Antigo porto clandestino da Coroa Portuguesa, que recebia as pedras preciosas que vinham da Chapada Diamantina, através do Rio de Contas. Chegando ao "status" de Município em 1932.

Em meados do Século XIX, deu-se início no Município de Itacaré o ciclo da Lavoura do Cacau que impulsionou a economia local. No período áureo, o dinheiro do ganho do cacau, apelidado de "Ouro Negro", ajudou a erguer os casarões e sobrados que ainda hoje marcam a arquitetura do Município. No final da década de 80 , um fungo conhecido vulgarmente como "Vassoura-deBruxa" $^{\prime 9}$ dizimou a maioria das plantações e o Município entrou em declínio.

Apesar da crise da Lavoura Cacaueira, o cacau contribuiu decisivamente para a preservação da Mata Atlântica. Segundo Milton Santos (1957), são íntimas as relações do cacaueiro com a floresta. Se a preserva, com a prática do cabrocamento, que é o plantio sem destruição do manto florístico, são às árvores de maior porte que protegem o crescimento do cacaueiro e, afinal, vão ajudarlhe a própria frutificação. A plantação de cacau fica sendo simplesmente um verdadeiro sub-bosque, ensombrada pela floresta persistente.

A região Sul da Bahia, mais especificamente a faixa compreendida entre os Rios Jequitinhonha e Contas, conserva a parcela mais significativa da Mata Atlântica do Nordeste do Brasil. As florestas desta região são caracterizadas por árvores altas com folhas sempre verdes. Sobre os troncos das árvores encontram-se dezenas de orquídeas, bromélias, cactáceas, ou seja, epífitas perfeitamente adaptadas a vida longe do solo.

\section{Impactos socioambientais}

O PRODETUR da Bahia, em sua primeira fase, investiu US\$231,3 milhões. O Pólo Litoral Sul recebeu investimentos provenientes do BID que somam US\$21,2 mi- lhões, sendo que destes a pavimentação da Rodovia BA-001 Ilhéus a Itacaré foi a obra que consumiu mais recursos: US\$ 18,058 milhões, ou 77,5\% do total do pólo.

Com a conclusão da Estrada Parque em 1998, um trecho de $65 \mathrm{Km}$, da BA-001, ligando os Municípios de Ilhéus a Itacaré, verificouse um significativo aumento do fluxo de turistas para Itacaré, na alta temporada, que no ano de 2005 passou a receber cerca de 120 mil turistas, um número seis vezes maior que a sua população. Na verdade a estrada configurou-se como um vetor de desenvolvimento regional atraindo empresários de outras regiões brasileiras e de outros países.

Tal evento foi responsável direto pelo surgimento de alguns problemas graves, para a comunidade local, a saber: crescimento econômico desordenado, falta de infra-estrutura, degradação ambiental, poluição, ocupação desordenada dos espaços (favelas), importação, vazamento da renda e especulação imobiliária. Dentre esses dados o crescimento desordenado é o mais grave, uma vez que este se torna gerador de todos os outros problemas. Qualquer crescimento pressupõe um planejamento, seja o crescimento da atividade turística ou da expansão do Município. Dentro desse planejamento deve estar em posição igualitária com os interesses econômicos, a preocupação com o bem estar social e com o meio ambiente. Como afirma Doris Ruschmann (1997, p.10):

o planejamento é fundamental para o desenvolvimento turístico equilibrado e em harmonia com os recursos físicos, culturais e sociais das regiões receptoras, evitando assim, que o turismo destrua as bases que o fazem existir.

A partir da ascensão do turismo no Município de Itacaré, muitas pessoas foram atraídas a fixar residências, nesta localidade, embora em diferentes esferas. Empresários e empreendedores ávidos por obter lucros do turismo, em sua maioria, despreparados para lhe dar com tal atividade (TORRES, 1999). Pessoas dos grandes centros urbanos em busca de melhor qualidade de vida, seguindo uma nova tendência migratória da década de 90 (REBOUÇAS, 2002). Pessoas das cidades e regiões circunvizinhas em busca de oportunidades de emprego no setor turístico e por fim moradores da zona rural, expulsos pela crise do cacau (REIS, 2002). 
Todo esse contingente populacional foi distribuído espacialmente de acordo com o seu poder aquisitivo e ocasionando uma redistribuição da população local. Os empresários e empreendedores, mais abastados, ocupara a parte central da cidade e os pontos mais valorizados pelo turismo, à beira mar ou rio, assim como os migrantes de maior poder aquisitivo. Pode-se observar nestes locais empreendimentos voltados para o turismo, pousadas, restaurantes, agências de turismo, e também belas residências. Os outros extratos sociais foram absorvidos nos bairros periféricos. Assim, favelas surgiram, como o Santo Antônio, na entrada da cidade. Outras áreas particulares foram invadidas e degradada no ano de 2001.

Outro fato que chama a atenção nestas transformações sócio-espaciais é que os autóctones foram sendo gradativamente empurrados para os bairros periféricos pois, a terra que antes era trocada por eletrodomésticos devido ao seu baixo valor, segundo depoimento de um antigo morador, teve o seu valor agregado em função da atividade turística após a construção da estrada. Deslumbrados pela oportunidade de lucros em curto prazo, venderam suas propriedades e no caso de posseiros, suas terras foram reclamadas pelos donos.

Conforme Archer e Cooper (2002) à medida que o turismo continua a crescer em dada região, suas exigências sobre os recursos escassos da área são cada vez maiores. É então, necessário, sobretudo, terra, e conseqüentemente o preço deste recurso se eleva. Os donos de terra locais são incentivados a vender a sua propriedade, e o resultado é que, embora possam obter ganhos à curto prazo, no final, a única coisa de que eles dispõem é de seu trabalho de baixa remuneração. Na verdade, a maior parte do benefício decorrente da elevação dos preços da terra é recebida pelos especuladores, que compram-na dos proprietários anteriores antes de ter sido designada para um empreendimento turístico.

Ainda, segundo Bandeira (2002), o preço dos alimentos e outros produtos básicos subiram tornando assim o custo de vida mais caro para os autóctones, que em sua maioria tem pouca renda.

O grande fluxo de turistas concentrados na alta estação, tem contribuído para a degradação ambiental (poluição das praias, lixo e desmatamento). Isto revela que o consumo do espaço turístico não está se dando de forma sustentável, não está sendo respeitada a capacidade de carga ambiental, que é a quantidade de turistas que um local pode suportar sem causar maiores impactos ao meio ambiente. O que já começou a ocorrer em Itacaré é a degradação dos atrativos naturais, os quais representam o próprio produto turístico, podendo dessa forma comprometer o futuro da atividade local.

Segundo Ruschmann (1997) como o meio ambiente constitui um elemento fundamental do turismo, sua alimentação "sadia" é essencial para a evolução da atividade. E, a motivação "contato com a natureza" se torna cada vez mais intensa, a natureza intacta pode tornar-se economicamente viável desde que associado á proteção dos espaços naturais e à existência dos serviços e equipamentos oferecidos aos turistas.

O impacto a esses espaços naturais não se restringe apenas a natureza, a comunidade local e sua cultura também sofrem estes impactos, desde quando o cotidiano da cidade é modificado e novos valores são introduzidos na comunidade. Quando esta cultura importada passa a predominar, a cultural local perde seu valor, causando verdadeiros conflitos entre a população nativa que não consegue se adequar aos novos costumes.

No Município de Itacaré observa-se uma acentuada exclusão social da população local e marginalização de sua cultura. Os lucros do turismo não estão proporcionando uma melhoria na qualidade de vida dos mais carentes. As políticas priorizam os empresários, atraindo cada vez mais investimentos sem o devido planejamento.

Os nativos acabam sendo excluídos do mercado de trabalho, pois não estão qualificados, perdendo a vaga para pessoas de outras localidades com um nível de educação maior. Segundo Reis (2002), a educação é um grande problema para este Município. Em Itacaré, só há uma escola que oferece o nível médio e cursos profissionalizantes, não existem. $\mathrm{O}$ autor sugere a implantação destes tipo de curso, em especial ligado ao turismo, para preparar a população para este novo mercada de trabalho. Dessa maneira, as oportunidades de emprego são absorvi- 
das por pessoas que chegam de outras cidades e que dispõem de capacitação. Mesmos os nativos que são incluídos no mercado formal, sofrem problemas com contratos temporários, não conseguindo estabilidade e os cargos ocupados em sua maioria são de baixa remuneração.

Todas estas agressões a comunidade tradicional do Município de Itacaré, abrem espaço para que os excluídos encontrem como estratégia de sobrevivência meios ilícitos como a prostituição e o tráfico de drogas.

Sintonizados com esta problemática, e como esses novos tempos, em Itacaré, o Txai $^{10}$ Resort, num exemplo de Responsabilidade Social, vem desenvolvendo um projeto intitulado "Companheiros do Txai", que trabalha com a comunidade rural que está localizada no entorno do seu empreendimento, onde promove ações no sentido de conscientizar essa população da importância da conservação e preservação dos recursos naturais (fauna e flora), criando alternativas de geração de emprego e renda para esta comunidade através da reciclagem do lixo do próprio Resort, cultivo de horta, produção de plantas ornamentais e confecção de peças artesanais que são adquiridas pelo próprio Txai. Mais recentemente, a ONG $Y_{o n i c^{11}}$, uma organização de caráter sócioambiental, que vem atuando na sede do Município, hoje responsável pela coleta de lixo, vem promovendo oficinas de artesanato, visando criar uma alternativa de ganho para os nativos na baixa temporada, com ênfase na reciclagem do lixo e utilização dos recursos naturais disponíveis (como a palha do coco), além de ter criado um cursinho prévestibular, que é oferecido gratuitamente a comunidade carente.

\section{Impactos econômicos}

Segundo Fernandes (2002), os resultados positivos ou negativos dos impactos econômicos do turismo sobre uma comunidade dependerão, em grande parte, do grau de desenvolvimento da região em estudo, pois qualquer indústria pode acarretar dois tipos de efeitos sobre a economia: a) intensa atividade de investimento, com períodos de expansão quando da sua implantação; e b) operação propriamente dita.
No entanto, é bom frisar que em ambos os casos o volume dos impactos dependerá da capacidade da economia local em fornecer os bens e serviços demandados pelo setor turístico. Se por exemplo, um hoteleiro que esteja ampliando seu empreendimento tiver todas as condições necessárias, tais como materiais de construção de boa qualidade e com preços acessíveis, mão-de-obra, etc., melhor para ele e para a cidade. Caso contrário irá buscar essas facilidades em outro lugar.

Mais que impactos econômicos são esses?

- Redução dos desequilíbrios regionais;

- Contribuição na arrecadação de impostos;

- Efeitos multiplicadores de renda, produção e emprego;

- Contribuição na formação do Produto Interno Bruto (PIB).

Muitos lugares ao redor do mundo apresentam regiões subdesenvolvidas ou relativamente subdesenvolvidas dentro do país em que elas se encontram. No Brasil, por exemplo, as regiões localizadas principalmente no Norte, Nordeste e Centro-Oeste exibem condições socioeconômicas bem aquém da média do país como um todo.

O Município de Itacaré, não foge a esta regra. Apresenta elevado nível de pobreza. Segundo dados da Confederação Nacional dos Municípios (CNM), a intensidade da pobreza em Itacaré, que em 1991 era de $57,85 \%$, reduziu para $54,00 \%$ em 2000 . Também, no mesmo período houve uma melhora do IDH (Índice de Desenvolvimento Humano), que em 1991 era de 0,472 e que em 2000 , passou a ser 0,588 . Tal fato demonstra uma pequena melhoria na qualidade de vida no Município de Itacaré, provocada pelo desenvolvimento da atividade turística.

Com relação aos efeitos multiplicadores da renda, produção e emprego. O impacto econômico dos gastos turísticos nos $\mathrm{MH}^{\prime} \mathrm{s}^{12}$ sobre a geração de renda turística do Município de Itacaré, conforme Leal (2005), revela que o Município apresenta um multiplicador do rendimento turístico igual a 1,0849. Ou seja, os gastos efetuados pelos $\mathrm{MH}^{\prime}$ s de Itacaré geram um efeito multiplicador de 1,0849 , causando um impacto de $8,49 \%$ sobre a economia do Município, além do gasto original. 
Conclui-se um baixo impacto das despesas turísticas sobre a renda turística de Itacaré. Esse resultado pode ser justificado pelas consideráveis evasões decorrentes das importações e das arrecadações fiscais.

A capacidade de uma determinada economia para reter o rendimento turístico nela gerado depende da capacidade produtiva da mesma. Portanto, quanto maior for esta capacidade, maior será a renda gerada pela despesa inicial. Em contraposição, quanto maiores os vazamentos, menor será essa renda.

Nesse sentido, a magnitude do multiplicador gerada em um certo destino turístico (neste caso, Itacaré) depende do nível de integração do turismo na economia local, da capacidade desta economia para corresponder à demanda de bens e serviços a que o dispêndio turístico produz, assim como da propensão a consumir dos receptadores da renda; das importações a que esse rendimento deu espaço e do nível de gastos dos turistas. Portanto, essas são as condições para impetrar um multiplicador expressivo, as quais ocorrem, sobretudo nas economias diversificadas.
Entretanto, o Município de Itacaré não satisfaz essas condições, haja vista a insuficiência na oferta de bens e serviços para o atendimento das diversas etapas da demanda gerada pelos gastos turísticos.

No que se refere aos motivos que levam os estabelecimentos de hospedagem a importarem bens e serviços fora da economia de Itacaré, $57,5 \%$ dos entrevistados responderam que em Itacaré os preços são maiores, $32,5 \%$ declararam que em Itacaré a qualidade do bem/serviço é inferior e 10\% revelaram que não há oferta do bem/serviço no Município.

Apesar da atividade turística em Itacaré, só ter sido iniciada de forma empresarial, a partir de 1998, com a pavimentação da Estrada Parque (BA-001) que liga Ilhéus a Itacaré. O setor de serviços neste Município tem se destacado, e no período de 2001 a 2002, superou o setor agropecuário que em décadas anterior representava o segmento mais expressivo, devido à monocultura do cacau, atualmente em franca decadência, conforme poderemos verificar na Tabela 1, a seguir.

Tabela 1 - Produto Interno Bruto de Itacaré - BA, Período 2001 a 2002. Em R\$.

\begin{tabular}{|l|r|r|}
\hline \multicolumn{1}{|c|}{ Setores } & \multicolumn{1}{c|}{ Ano - 2001 } & \multicolumn{1}{c|}{ Ano - 2002 } \\
\hline Agropecuária & $9.545 .000,00$ & $19.421 .000,00$ \\
\hline Indústria & $3.182 .000,00$ & $3.177 .000,00$ \\
\hline Serviços & $16.551 .000,00$ & $20.650 .000,00$ \\
\hline
\end{tabular}

Fonte: IBGE (2006).

\section{Considerações finais}

O estudo do Município de Itacaré revela como o território se transforma para oferecer as condições necessárias à racionalidade hegemônica do grande capital. Esses "vetores verticais" estabelecem uma nova ordem, uma nova organização espacial não construída efetivamente pelos atores locais. Conforme Milton Santos (2001), tratam-se de ordens "estranhas" e impostas de fora com o aval do Estado que alteram profundamente o cotidiano e a especificidade do lugar.

Para Just Krippendorf (2000), a "divisão do trabalho" entre a cidade e o campo é desigual e injusta. Não é preciso ser marxista ou ter estudado ciências econômicas para saber que "é o dinheiro que comanda". $\mathrm{Na}$ indústria do turismo, o dinheiro vem dos grandes centros, das zonas altamente produtoras e é para lá que volta, na maioria das vezes. É claro que às populações das periferias dispõem de dois outros meios de produção indispensável: o solo e o trabalho. Mas os habitantes e os empresários e empreendedores das metrópoles podem adquiri-los a preços módicos. Para obterem vantagens da fortuna que proporciona o turismo, os autóctones vendem o trabalho e o solo a preços baixos. 
Segundo Reinaldo Dias (2003), o turismo foi durante muito tempo considerado uma atividade econômica limpa, não poluente e geradora de amplo leque de oportunidades. Contrariando essa hipótese, os resultados preliminares obtidos com esta pesquisa, vem desnudar as outras faces da atividade turística em curso neste núcleo receptor, a saber: crescimento desordenado, degradação ambiental, especulação imobiliária, exclusão da população nativa, importação, ocupação desordenada dos espaços urbanos (favelas), prostituição, tráfico de drogas e vazamento da renda.

Por fim, levando-se em consideração os dados da HVS Internacional, responsável por prestar consultoria ao Instituto de Turismo de Itacaré (ITI), o fluxo anual de turistas para o destino é de 120.000. Segundo alguns estudos, a capacidade de carga do Município é de cerca de 20.000 turistas. Diante deste fato, fica evidente, que é necessário criar estratégias para combater essa concentração principalmente na alta estação. Pois tal ocorrência é extremamente grave, pondo em risco a sustentabilidade da atividade turística a longo prazo.

\section{Notas}

${ }^{1}$ Organização Mundial de Turismo.

2 Órgão Oficial de Turismo da Bahia.

${ }^{3}$ Banco Interamericano de Desenvolvimento.

${ }^{4}$ Banco do Nordeste do Brasil.

${ }^{5}$ Instituto Brasileiro de Geografia e Estatística.

${ }^{6}$ Instituto de Estudos Socioambientais do Sul da Bahia.

${ }^{7}$ Instituto de Turismo de Itacaré.

${ }^{8}$ Tour Operators Initiative.

${ }^{9}$ Nome Científico do Fungo "Crinipelis perniciosas" (OLIVEIRA, 2004).

${ }^{10}$ Palavra da língua dos índios kaxinawá (do Acre) que significa mais do que companheiro, a outra metade de cada um.

${ }^{11}$ Palavra grega que quer dizer a força feminina.

${ }^{12}$ Meios de Hospedagem (albergues, hotéis e pousadas).

\section{Referências}

BAHIATURSA. Oferta hoteleira costa do cacau: município de Itacaré. Salvador: DST - Diretoria de Serviços Turísticos. Disponível em: http://www.bahiatursa.gov.br. Acessado em: 15 mar. 2006.

BANDEIRA, A. da S. A política do turismo na Bahia e a apropriação do espaço litorâneo: o exemplo de Itacaré. 2002. 237p. Dissertação (Mestrado em Geografia) Universidade Federal da Bahia.
BARRETO, Margarida. O imprescindível aporte das ciências sociais para o planejamento e a compreensão do turismo. Horizontes Antropológicos, v. 9, n. 20, p. 1529, out. 2003. ISSN 0104-7183.

BARTELÓ, Cassandra. Costas da Bahia. ViverBAHIA, Salvador, ano 5, n. 8, p. 30-31, 200.

Novos destinos na Bahia. ViverBAHIA, Salvador, ano 5, n. 8, p. 6, 200.

BONFIM, Marcos Vinicius. Análise da capacidade de geração de emprego e renda setor de alimentos e bebidas da cadeia produtiva do turismo no município de Ilhéus. 2001. 57p. Monografia (Graduação em Economia) - UESC.

CNM. Confederação Nacional de Municípios. Informações municipais: Itacaré-BA. Disponível em: http:// www.portalmunicipal.org.br/v6/economia/... Acesso em: 22 mar. 2006.

COOPER, Chris et al. Turismo: princípios e práticas. 2. ed. Porto Alegre: Bookman, 2001. 559p.

DIAS, Reinaldo. Turismo sustentável e meio ambiente. São Paulo: Atlas, 2003.

DOLIS, Rosangela. Consciência ecológica, a chave do sucesso de Itacaré. Disponível em: http:/ / www.estadao.com.br/ parceiro/click21/notícias/2003/dez/03/97.htm. Acesso em: dez. 2003.

FERNANDES, Ivan Pereira; COELHO, Márcio Ferreira. Economia do turismo. Rio de Janeiro: Elsevier, 2002.

IBGE. Cidades. Disponível em: http:/ / www.ibge.gov.br/ cidadesat/... Acesso em: 22 mar. 2006.

ITI. Instituto de Turismo de Itacaré. Plano Itacaré 2.015. HVS Internacional. Itacaré, 2005.

KENT, Micel. The Hidden Stone Discovered: tourism, environmental preservation and social conflict in the Brazilian town of Itacaré; an Analysis of discourses. MA - Thesis in Cultural Anthropology. Vrije Universiteit, Amsterdam, August 2000.

KRIPPENDORF, Just. Sociologia do turismo: para uma nova compreensão do lazer e das viagens. Trad.: Contexto Traduções. São Paulo: Aleph, 2000. (Série Turismo). 186p.

LAGE, Beatriz Helena Gelas; MILONE, Paulo César. Economia do turismo. Campinas, SP: Papirus, 1991 (Coleção Turismo). 122p.

LEAL, Flávia Pereira. O multiplicador turístico de ItacaréBA: o caso dos meios de hospedagem. 2005. 44p. Monografia (Graduação em Economia) - UESC.

LINDBERG, Kreg; HAWKINGS, E. Donald. Ecoturismo: um guia para o planejamento e gestão. 2. ed. São Paulo: [s.n.], 1999. 289p.

MOESCH, Marutschka Martini. A produção do saber turístico. 2. ed. São Paulo: Contexto, 2002.

MOREAU, Ana Maria S. Santos. O potencial ecoturístico de Itacaré: repercussões no desenvolvimento sustentável do município. ENCONTRO NACIONAL DE TURISMO COM BASE LOCAL, 7. Anais... Ilhéus: Editus, 2004. 13p.

MOREAU, Maurício Santana. Mapa de localização do município de Itacaré - Bahia. 1 mapa. Escala 02.55-10 Km. 2006. 
OLIVEIRA, Elton Silva. O perfil da demanda turística nos municípios de Ilhéus e Itacaré, Bahia: uma análise comparativa para o ano de 2002. 2004. 39p. Monografia (Graduação em Economia) - UESC.

OMT. Organização Mundial do Turismo. Turismo internacional: uma perspectiva global. 2. ed. Porto Alegre: Bookman, 2003.

REIS, D.S.J. dos. Comportamentos de indicadores socioeconômicos do município de Itacaré de 1971 a 1996. 2002. 56p. Monografia (Graduação em Economia) - UESC.

REBOUÇAS, R.C. As faces do turismo em Itacaré. ENCONTRO BAIANO DE GEOGRAFIA, 6. Anais... Salvador: Editus, 2002. 8p.

RUSCHMANN, Dóris Van de Meene. Turismo e planejamento sustentável: a proteção do meio ambiente. 3. ed. Campinas: Papirus, 1997. (Coleção Turismo). 199p.

SANTOS, Milton. Zona do Cacau: introdução ao estudo geográfico. 2. ed. São Paulo: Companhia Editora Nacional, 1957.
Por uma outra globalização: do pensamento único à consciência universal. 6. ed. Rio de Janeiro: Record, 2001.

SCHLÜTER, Regina G. Metodologia de pesquisa em turismo e hotelaria. Trad. Tereza Jardini. São Paulo: Aleph, 2003. (Série Turismo). 192p.

SOUZA, Ana Paula Andrade. O turismo como transformador do espaço em Ilhéus e Itacaré, Bahia. 2005. 129p. Dissertação (Mestrado em Cultura e Turismo) UESC.

TOI. Tour Operators Initiative: for sustentable turism development. Destino Itacaré, Bahia, Brasil - Relatório. Novembro, 2005. 12p.

TORRES, A. P. Capacidade de carga turística como fator de sustentabilidade ambiental: o caso da cidade de Itacaré. 2001. 51p. Monografia (Graduação em Economia) UESC. 